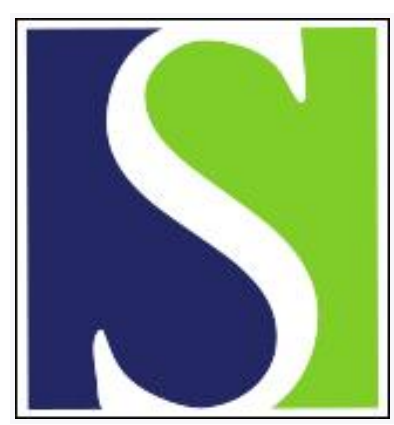

Scand J Work Environ Health 1976;2(4):225-231

https://doi.org/10.5271/sjweh.2800

Issue date: Dec 1976

Relationships between lead absorption and peripheral nerve conduction velocities in lead workers.

by Araki S, Honma T

Key terms: conduction velocity; delta-aminolevulinic acid dehydratase; dose-response relationship; lead; lead absorption; lead mobilization; lead mobilization test; lead mobilization test (with CaEDTA); lead worker; multivariate analysis; nerve conduction; peripheral nerve; peripheral nerve conduction velocity; subclinical neuropahty; worker

This article in PubMed: www.ncbi.nlm.nih.gov/pubmed/1019597

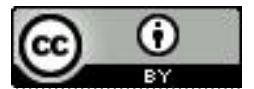


Scand. j. work environ. \& health 4 (1976) 225-231

\title{
Relationships between lead absorption and peripheral nerve conduction velocities in lead workers
}

\author{
by SHUNICHI ARAKI, M.D., D.Med.Sc., ${ }^{1}$ and TETSUO HONMA, B.P.E. ${ }^{2}$
}

\begin{abstract}
ARAKI, S. and HONMA, T. Relationships between lead absorption and peripheral nerve conduction velocities in lead workers. Scand. $j$. work environ. \& health 4 (1976) 225-231. The motor, sensory, and mixed nerve conduction velocities of median and posterior tibial nerves were measured in 39 lead workers whose blood lead (PbB) concentrations ranged from 2 to $73 \mu \mathrm{g} / 100 \mathrm{~g}$ with an average of $29 \mu \mathrm{g} / 100 \mathrm{~g}$. The $\mathrm{PbB}$ concentrations significantly correlated with the maximal motor nerve conduction velocities (MCV) and mixed nerve conduction velocities (MNCV) of the median nerve in the forearm and with the MCV of the posterior tibial nerve. Erythrocyte $\delta$-aminolevulinic acid dehydratase (ALAD) activity correlated similarly with the MCV and MNCV of the median nerve in the forearm, and the 24-hour urinary lead excretion following the intravenous administration of CaEDTA $(20 \mathrm{mg} / \mathrm{kg})(\mathrm{lead}$ mobilization test) correlated with the MNCV. But no parameter correlated with the sensory nerve conduction velocities. By multiple regression analysis, a combination of the three parameters of lead absorption was found to correlate significantly with the MCV and MNCV of the median nerve in the forearm. The MCVs of the median and posterior tibial nerves in lead workers were significantly delayed in the $\mathrm{PbB}$ range of $29-73 \mu \mathrm{g} / 100 \mathrm{~g}$ (mean 45), in the lead mobilization test range from 173 to $3,540 \mu \mathrm{g} /$ day (mean 973 ), and the ALAD activity range from 4.4 to $19.4 \mathrm{u}$. (mean 14.0), respectively.
\end{abstract}

Key words: lead absorption, peripheral nerve conduction velocities, lead workers, subclinical neuropathy, dose-response relationship, multivariate analysis, blood lead, lead mobilization test (with CaEDTA), $\delta$-aminolevulinic acid dehydratase.

Motor nerve involvement of the upper and lower extremities is one of the distinguishing manifestations in "classical" lead poisoning (2), and developments in electrophysiology have made it possible to perceive diminished nerve conduction velocities in those people with symptoms of lead poisoning but no signs of neurol-

1 Department of Public Health, Faculty of Medicine, The University of Tokyo, Tokyo, Japan.

2 Department of Clinical Physiology, Tokyo Rosai (Labor Accident) Hospital, Japan.

Reprint requests to: Dr. Shunichi Araki, Department of Public Health, Faculty of Medicine, The University of Tokyo, Hongo, Bunkyo-ku, Tokyo, Japan. ogical involvement $(3,6,8,10)$. Recently a slight but significant slowing of motor nerve conduction velocities was revealed in lead workers without special symptoms of lead poisoning (9) and with such low levels of blood lead concentrations as $40 \pm 9 \mu \mathrm{g} / \mathrm{dl}$ (7). However, the direct relationships between parameters of lead absorption and nerve conduction velocities have not been confirmed previously, except in a preliminary report by one of the present authors (1).

Therefore blood lead ( $\mathrm{PbB})$, a lead mobilization test with CaEDTA, and erythrocyte $\delta$-aminolevulinic acid dehydratase (ALAD) activity were selected and their relationships with nerve conduction velocities were analyzed for lead workers 
with no clinical manifestations of lead poisoning.

\section{SUBJECTS AND METHODS}

\section{Subjects}

The subjects studied were 36 male workers who had been exposed to lead occupationally from 8 months to 46 years with an average of 18 years: 24 workers in a newspaper company, 4 lead mill workers, 3 plastics workers, 2 lead smelters, 2 glassmakers, 1 batterymaker, 1 brass founder, 1 welder, and 1 plumber. The mean age was 41 years, ranging from 21 to 60 years. The mean intake of alcohol was less than 0.541 of Sake (Japanese wine) a day for all workers except one. None of them had ever suffered from neurological, endocrinological, or renal diseases. The $\mathrm{PbB}$ of all the subjects ranged from 2 to 73 $\mu \mathrm{g} / 100 \mathrm{~g}$ with an average of $29 \mu \mathrm{g} / 100 \mathrm{~g}$. Similarly the 24-h urinary lead excretion following the intravenous administration of CaEDTA $(20 \mathrm{mg} / \mathrm{kg}$ ) (lead mobilization test) ranged from 47 to $3,540 \mu \mathrm{g}$ of lead/ day with an average of $781 \mu \mathrm{g}$ of lead/day for the 27 workers receiving the test; and the erythrocyte ALAD activity of 29 workers, from 4.4 to $62.3 \mathrm{u}$. (mean $23.0 \mathrm{u}$.) by the method of Weissberg et al. (11). There were no significant correlations between age and $\mathrm{PbB} \quad(\mathrm{r}=-0.021$, $p>0.25)$ or between age and the other parameters.

\section{Nerve conduction velocities}

The motor, sensory and mixed nerve conduction velocities of median and posterior tibial nerves were measured at the peripheral parts of the upper and lower extremities in most of the workers and at the proximal part of the limbs in some workers in a warm laboratory $\left(25\right.$ to $\left.27^{\circ} \mathrm{C}\right)$. The technique for the determination of the conduction velocities is presented in the following text:

Maximal motor nerve conduction velocity $(M C V)$. The nerves were stimulated ten times repeatedly with a couple of silver band electrodes using a supramaximal square wave pulse with a duration of 0.4 to $0.6 \mathrm{~ms}$. The stimulating cathode was placed near the nerves at three points on the right upper limb, i.e., $10 \mathrm{~cm}$ above the elbow, on the elbow and on the wrist, and at two points on the right lower limb, i.e., on the popliteal fossa and on the medial malleolus. The anode electrode was placed $2.5 \mathrm{~cm}$ distal from the same points. The muscular responses were picked up with surface electrodes taped on the belly of the thenar muscle and the abductor digiti minimi muscle in the palm and sole, respectively. The responses were amplified by the use of Sanei UB 204, averaged with an averaging data processor (Nihon Kohden ATAC 201) and then recorded on a $X-Y$ Recorder (Yokogawa 3077). The latency of the response to the stimulation was measured from the beginning of the stimulation artifact to the first positive peak of the response or the start of the negative potential. The distance between the stimulation points was carefully measured with a tape measure. Conduction velocities were calculated for the area between the axilla and the elbow, between the elbow and the wrist, and between the knee and the ankle, respectively. For each area the distance between the two points of stimulation was divided by the difference in the latency of the response to get the velocity in $\mathrm{m} / \mathrm{s}$.

Residual latency $(R L)$. Residual latency represents a measured period of time in excess of a calculated period of time. In this study it was calculated according to Hodes et al. (5) as follows: $\mathrm{RL}=\mathrm{t}-\mathrm{d} / \mathrm{MCV}$,

where $t$ is the time required for nerve impulses to travel from the stimulating point to the muscle; $d$ is the distance between the stimulating point and the recording point; MCV is the maximal conduction velocity as determined in the preceding section.

Sensory nerve conduction velocity $(S C V)$. Sensory nerves were stimulated repeatedly with a silver ring cathode, tied around the middle phalanx of the second finger, and with an anode electrode, tied $2 \mathrm{~cm}$ distal on the same finger, with a $60 \mathrm{~V}$ square wave pulse of $0.2 \mathrm{~ms}$ duration.The stimulating cathode was similarly tied at the base of the great toe and the anode electrode was tied $2 \mathrm{~cm}$ distal on the same toe. Action potentials were picked up with 
Table 1. Nerve conduction velocities $(\mathrm{m} / \mathrm{s})$ and residual latency $(\mathrm{ms})$ of lead workers. (MCV = maximal motor nerve conduction velocity; $\mathrm{RL}=$ residual latency; SCV = sensory nerve conduction velocity; $M N C V=$ mixed nerve conduction velocity)

\begin{tabular}{|c|c|c|c|}
\hline Conduction velocities & Number & Mean & SD \\
\hline \multicolumn{4}{|l|}{ Median nerve } \\
\hline MCV (axilla to elbow) & 16 & 59.7 & 8.6 \\
\hline MCV (elbow to wrist) & 38 & 58.1 & 7.6 \\
\hline RL & 39 & 2.7 & 0.6 \\
\hline SCV (finger to wrist) & 35 & 53.2 & 6.7 \\
\hline SCV (wrist to elbow) & 17 & 59.6 & 4.6 \\
\hline SCV (elbow to axilla) & 16 & 68.5 & 14.1 \\
\hline MNCV (wrist to elbow) & 36 & 66.6 & 6.4 \\
\hline MNCV (elbow to axilla) & 17 & 69.0 & 10.6 \\
\hline \multicolumn{4}{|l|}{ Posterior tibial nerve } \\
\hline MCV (knee to ankle) & 37 & 46.9 & 5.1 \\
\hline RL & 37 & 2.3 & 1.2 \\
\hline SCV (toe to ankle) & 12 & 48.6 & 3.5 \\
\hline SCV (ankle to knee) & 10 & 54.6 & 11.8 \\
\hline MNCV (ankle to knee) & 17 & 57.7 & 5.3 \\
\hline
\end{tabular}

Table 2. Correlations between three parameters of lead absorption and nerve conduction velocities. [ $r=$ correlation coefficient; $R=$ multiple correlation coefficient; $R^{2}=$ percentage of total variance explained by multiple regression equation (coefficient of determination)]

\begin{tabular}{|c|c|c|c|c|c|c|c|c|c|}
\hline \multirow[t]{2}{*}{$\begin{array}{l}\text { Conduction } \\
\text { velocities }\end{array}$} & \multicolumn{2}{|c|}{$\begin{array}{l}\mathrm{PbB} \text { vs } \\
\text { conduction } \\
\text { velocity } \\
\end{array}$} & \multicolumn{2}{|c|}{$\begin{array}{l}\text { Mob. test } \mathbf{a}, \mathbf{b} \text { vs } \\
\text { conduction } \\
\text { velocity } \\
\end{array}$} & \multicolumn{2}{|c|}{$\begin{array}{l}\text { ALAD b vs } \\
\text { conduction } \\
\text { velocity }\end{array}$} & \multicolumn{3}{|c|}{$\begin{array}{l}\mathrm{PbB} \text {, mob. test } \mathrm{a}, \mathrm{b} \\
\text { \& ALAD b vs } \\
\text { conduction velocity }\end{array}$} \\
\hline & $\mathrm{N}$ & $\mathrm{r}$ & $\mathrm{N}$ & $\mathrm{r}$ & $\mathrm{N}$ & $\mathrm{r}$ & $\bar{N}$ & $\mathbf{R}$ & $\mathrm{R}^{2}$ \\
\hline \multicolumn{10}{|l|}{ Median nerve } \\
\hline $\begin{array}{l}\text { MCV } \\
\text { (axilla to elbow) }\end{array}$ & 16 & -0.473 & 12 & 0.023 & 17 & 0.227 & 11 & 0.590 & 0.348 \\
\hline $\begin{array}{l}\text { MCV } \\
\text { (elbow to wrist) }\end{array}$ & 38 & $-0.527^{* * * *}$ & 26 & -0.363 & 28 & $0.446 *$ & 23 & $0.599 *$ & 0.359 \\
\hline RL & 39 & 0.076 & 27 & -0.023 & 29 & -0.178 & 24 & 0.343 & 0.118 \\
\hline $\begin{array}{l}\text { SCV } \\
\quad \text { (finger to wrist) }\end{array}$ & 35 & -0.104 & 24 & 0.119 & 26 & 0.032 & 21 & 0.449 & 0.202 \\
\hline $\begin{array}{l}\text { SCV } \\
\text { (wrist to elbow) }\end{array}$ & 17 & -0.102 & 12 & -0.352 & 17 & 0.153 & 12 & 0.411 & 0.169 \\
\hline $\begin{array}{l}\text { SCV } \\
\text { (elbow to axilla) }\end{array}$ & 16 & 0.128 & 11 & -0.085 & 16 & -0.121 & 11 & 0.174 & 0.030 \\
\hline $\begin{array}{l}\text { MNCV } \\
\text { (wrist to elbow) }\end{array}$ & 36 & $-0.451 * *$ & 24 & $-0.496 *$ & 26 & $0.476^{*}$ & 21 & $0.626 *$ & 0.392 \\
\hline $\begin{array}{l}\text { MNCV } \\
\text { (elbow to axilla) }\end{array}$ & 17 & 0.107 & 11 & -0.061 & 17 & -0.060 & 12 & 0.404 & 0.163 \\
\hline \multicolumn{10}{|l|}{$\begin{array}{l}\text { Posterior tibial } \\
\text { nerve }\end{array}$} \\
\hline $\begin{array}{l}\text { MCV } \\
\text { (knee to ankle) }\end{array}$ & 37 & $-0.480^{* * *}$ & 26 & -0.375 & 28 & 0.269 & 23 & 0.451 & 0.203 \\
\hline $\mathrm{RL}$ & 37 & -0.320 & 27 & -0.353 & 29 & 0.353 & 24 & 0.357 & 0.127 \\
\hline $\begin{array}{l}\text { SCV } \\
\text { (toe to ankle) }\end{array}$ & 12 & 0.481 & 7 & -0.464 & 13 & 0.040 & 9 & 0.704 & 0.496 \\
\hline $\begin{array}{l}\text { SCV } \\
\text { (ankle to knee) }\end{array}$ & 10 & 0.095 & 6 & -0.693 & 10 & -0.180 & 6 & 0.778 & 0.605 \\
\hline $\begin{array}{l}\text { MNCV } \\
\text { (ankle to knee) }\end{array}$ & 17 & -0.211 & 13 & -0.207 & 17 & 0.315 & 12 & 0.386 & 0.149 \\
\hline
\end{tabular}

a Lead mobilization test with CaEDTA.

b Transformed into logarithm.

${ }^{*} \mathrm{p}<0.05 ;{ }^{* *} \mathrm{p}<0.01 ; * * * \mathrm{p}<0.005 ; * * * \mathrm{p}<0.001$. 
surface electrodes at the wrist, elbow, axilla, ankle, and knee. The conduction velocities were calculated for the areas between the finger and the wrist, between the wrist and the elbow, between the elbow and the axilla, between the toe and
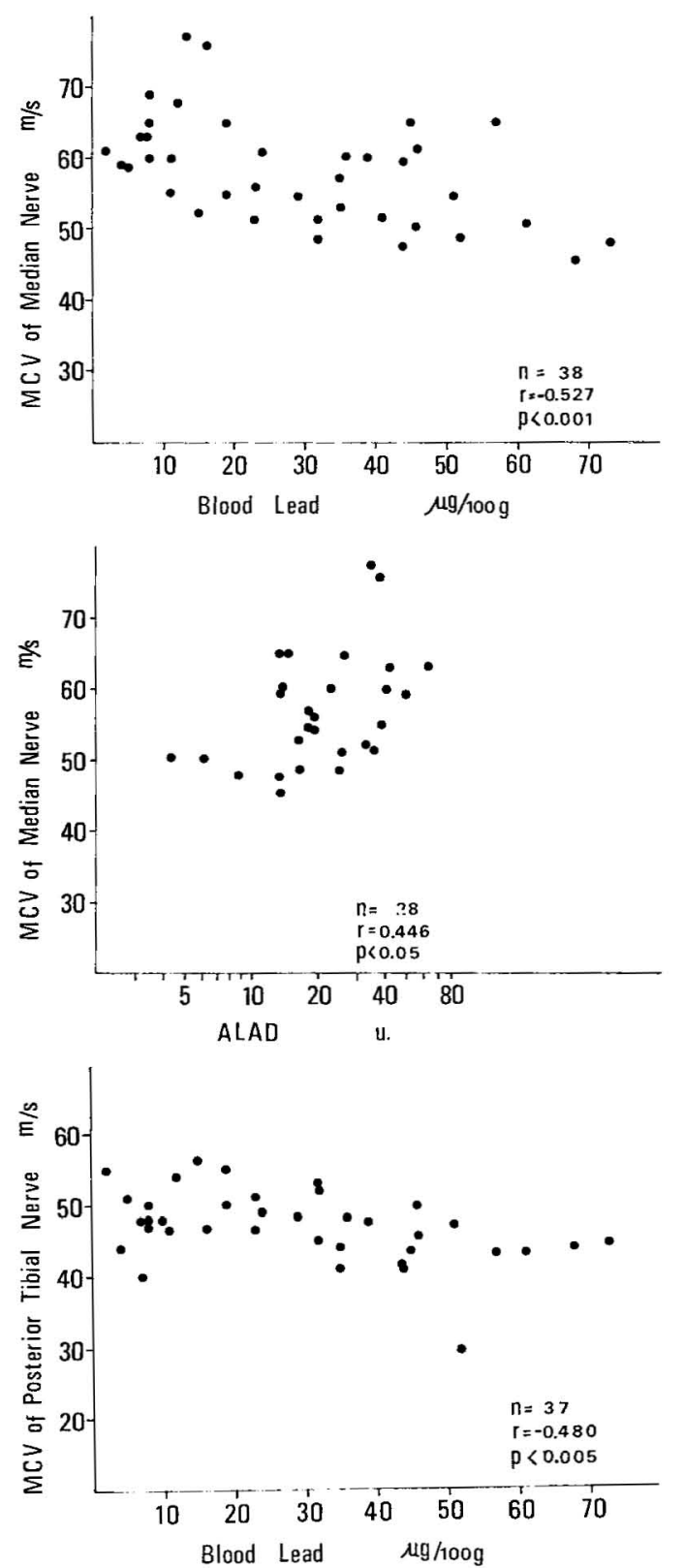

Fig. 1. Relationships between parameters of lead absorption and maximal motor nerve conduction velocities (MCV) of the median nerve in the forearm and of the posterior tibial nerve. the ankle, and between the ankle and the knee, respectively.

Mixed nerve conduction velocity (MNCV). A supramaximal square wave pulse of $0.2 \mathrm{~ms}$ duration was applied at the wrist and the ankle with the recording electrodes set for the measurement of SCV. Nerve action potentials were then recorded at the elbow, axilla and knee levels. The conduction velocities were calculated for the areas between the wrist and the elbow, between the elbow and the axilla, and between the ankle and the knee, respectively.

Precision and accuracy of the measurements of nerve conduction velocities

The nerve conduction velocities were measured for 10 successive days in a 22-yearold university student. When expressed as a coefficient of variance (standard deviation/mean value), the daily variations of the nerve conduction velocities were as follows: MCV (axilla to elbow), $10.1 \%$; MCV (elbow to wrist), $3.5 \%$; RL (palm), $9.6 \%$; SCV (finger to wrist), $3.5 \%$; SCV (wrist to elbow), $5.6 \%$; SCV (elbow to axilla), $10.2 \%$; MNCV (wrist to elbow), $4.5 \%$; MNCV (elbow to axilla), $7.8 \%$; MCV (knee to ankle), $3.0 \%$; RL (sole), $10.4 \% ; \mathrm{SCV}$ (toe to ankle), $5.4 \%$; SCV (ankle to knee), $5.0 \%$; and MNCV (ankle to knee), $8.6 \%$.

The conduction velocities measured in 39 "healthy" men without any particular exposure to neurotoxic chemicals or a history of peripheral neuropathy were as follows: MCV (elbow to wrist), $58.3 \pm 4.7$ $\mathrm{m} / \mathrm{s}$; MNCV (wrist to elbow), $68.3 \pm 4.8$ $\mathrm{m} / \mathrm{s} ; \mathrm{MCV}$ (knee to ankle), $49.5 \pm 5.5 \mathrm{~m} / \mathrm{s}$. There were no significant differences in the conduction velocities between 23 nondrinkers and 15 drinkers up to 0.541 of Sake a day.

Analysis of blood and urinary lead concentrations and erythrocyte ALAD activities

Blood and urinary lead concentrations were determined by atomic absorption spectrophotometry (Perkin-Elmer 403) with a procedure of wet ashing, chelation by ammonium pyrrolidine dithiocarbamate 
and extraction to water-saturated isobutylmethylketone. Erythrocyte ALAD activities were measured by the aforementioned method of Weissberg et al. (11). The ALAD activity of one unit corresponds to 0.03 $\mu$ mole porphobilinogen per milliliter of packed red blood cells per hour in this method.

The accuracy of the measurements of blood and urinary lead concentrations was tested several times by double analysis with the Occupational Health Service Center of the Japan Industrial Safety Association, and the results were satisfactory. The reproducibility of the determinations of urinary lead was $8.2 \%$, when expressed as a coefficient of variance.

The mean value of $\mathrm{PbB}$ was $12 \mu \mathrm{g} / 100 \mathrm{~g}$ in 25 male adults free from occupational exposure to lead; that of the lead mobilization tests, $95 \mu \mathrm{g} /$ day; and ALAD, $39.7 \mathrm{u}$. Similarly, the upper $95 \%$ confidence limits of $\mathrm{PbB}$ and the lead mobilization test were $25 \mu \mathrm{g} / 100 \mathrm{~g}$ and $170 \mu \mathrm{g} /$ day, respectively, the lower $95 \%$ confidence limit of erythrocyte ALAD activity being $20 \mathrm{u}$.

\section{Statistical analysis}

Multiple linear regression analysis was performed by the use of a Hitac 8700 at the University of Tokyo.

\section{RESULTS}

The nerve conduction velocities measured are listed in table 1 . The relationships between the three major parameters of lead absorption and conduction velocities are shown in table 2. The MCV of the median nerve in the forearm correlated significantly with the $\mathrm{PbB}$ level and the erythrocyte ALAD activity; and the MCV of the posterior tibial nerve, with the $\mathrm{PbB}$ level (fig. 1). Similarly, the MNCV of the median nerve in the forearm correlated with the $\mathrm{PbB}$ concentration, the lead mobilization test, and the ALAD activity (fig. 2). However, the SCVs did not correlate with any parameter (table 2).

When the three parameters of lead absorption were analyzed for the nerve conduction velocities by multiple regression analysis, the three parameters combined significantly correlated with the
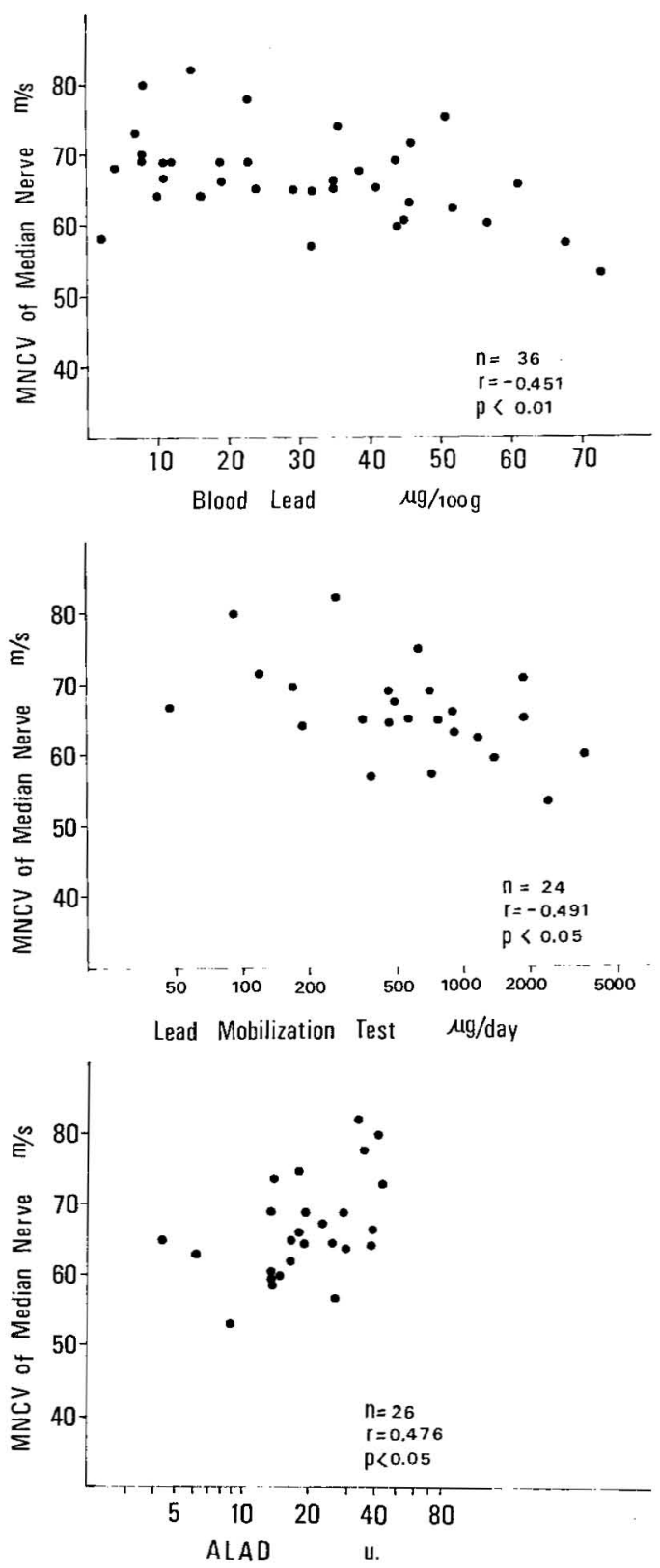

Fig. 2. Relationships between parameters of lead absorption and mixed nerve conduction velocities (MNCV) of the median nerve in the forearm.

MCV and MNCV of the median nerve in the forearm (table 2).

The MCV and MNCV of the median nerve in the forearm and the MCV of the posterior tibial nerve are compared between lead workers and age-matched "healthy" people in table 3 . When lead 
Table 3. Significant levels of diminished nerve conduction velocities in lead workers. (MCV $=$ maximal motor nerve conduction velocity; $\mathrm{MNCV}=$ mixed nerve conduction velocity)

\begin{tabular}{|c|c|c|c|c|c|c|c|}
\hline \multirow[t]{2}{*}{ Conduction velocities } & \multicolumn{3}{|c|}{$\begin{array}{l}\text { Lead workers } \\
\mathrm{PbB} 29-73\left(45^{\mathrm{a}}\right) \\
\mu \mathrm{g} / 100 \mathrm{~g}\end{array}$} & \multicolumn{3}{|c|}{ Control subjects } & \multirow[t]{2}{*}{$\begin{array}{c}\text { Level of } \\
\text { significance }\end{array}$} \\
\hline & $\mathrm{N}$ & Mean & $\mathrm{SD}$ & $\mathbf{N}$ & Mean & $\mathrm{SD}$ & \\
\hline $\begin{array}{l}\text { MCV (elbow to wrist) } \\
\text { MCV (knee to ankle) } \\
\text { MNCV (wrist to elbow) }\end{array}$ & $\begin{array}{l}19 \\
19 \\
19\end{array}$ & $\begin{array}{l}54.3 \\
44.7 \\
64.1\end{array}$ & $\begin{array}{l}6.0 \\
5.0 \\
5.7\end{array}$ & $\begin{array}{l}19 \\
19 \\
19\end{array}$ & $\begin{array}{l}59.0 \\
50.0 \\
67.1\end{array}$ & $\begin{array}{l}2.9 \\
6.2 \\
3.6\end{array}$ & $\begin{array}{l}p<0.01 \\
p<0.01 \\
p>0.05\end{array}$ \\
\hline Conductions velocities & \multicolumn{3}{|c|}{$\begin{array}{c}\text { Lead workers } \\
\text { Lead mobiliation test } \\
0.17-3.54(097 \mathrm{a}) \mathrm{mg} / \text { day }\end{array}$} & \multicolumn{3}{|c|}{ Control subjects } & $\begin{array}{c}\text { Level of } \\
\text { significance }\end{array}$ \\
\hline $\begin{array}{l}\text { MCV (elbow to wrist) } \\
\text { MCV (knee to ankle) } \\
\text { MNCV (wrist to elbow) }\end{array}$ & $\begin{array}{l}20 \\
21 \\
21\end{array}$ & $\begin{array}{l}54.6 \\
45.9 \\
65.2\end{array}$ & $\begin{array}{l}6.2 \\
5.7 \\
6.5\end{array}$ & $\begin{array}{l}20 \\
21 \\
21\end{array}$ & $\begin{array}{l}59.5 \\
49.5 \\
67.5\end{array}$ & $\begin{array}{l}3.3 \\
5.6 \\
3.6\end{array}$ & $\begin{array}{l}p<0.01 \\
p<0.05 \\
p>0.05\end{array}$ \\
\hline Conduction velocities & \multicolumn{3}{|c|}{$\begin{array}{c}\text { Lead workers } \\
\text { ALAD } 4.4-19.4\left(14.0^{a}\right) \\
\text { u. }\end{array}$} & \multicolumn{3}{|c|}{ Control subjects } & $\begin{array}{c}\text { Level of } \\
\text { significance }\end{array}$ \\
\hline $\begin{array}{l}\text { MCV (elbow to wrist) } \\
\text { MCV (knee to ankle) } \\
\text { MNCV (wrist to elbow) }\end{array}$ & $\begin{array}{l}15 \\
15 \\
15\end{array}$ & $\begin{array}{l}54.3 \\
43.8 \\
64.1\end{array}$ & $\begin{array}{l}6.1 \\
5.1 \\
5.9\end{array}$ & $\begin{array}{l}15 \\
15 \\
15\end{array}$ & $\begin{array}{l}58.4 \\
49.4 \\
68.0\end{array}$ & $\begin{array}{l}2.4 \\
5.8 \\
2.5\end{array}$ & $\begin{array}{l}p<0.05 \\
p<0.01 \\
p<0.05\end{array}$ \\
\hline
\end{tabular}

a Mean value.

workers with $\mathrm{PbB}$ values above the upper $95 \%$ confidence limit in nonexposed male adults are chosen, their MCVs in the forearm and leg are significantly delayed in the range of $\mathrm{PbB}$ from 29 to $73 \mu \mathrm{g} /$ $100 \mathrm{~g}$ (mean $45 \mu \mathrm{g} / 100 \mathrm{~g}$ ) on a group basis. Similarly the MCVs are significantly delayed in the ranges of the lead mobilization test from 173 to $3,540 \mu \mathrm{g} /$ day and ALAD activities from 4.4 to $19.4 \mathrm{u}$., respectively.

\section{DISCUSSION}

The significant correlations of the $\mathrm{PbB}$, concentrations and the lead mobilization tests with conduction velocities indicate the existence of a dose-effect relationship for lead in workers with PbBs below 73 $\mu \mathrm{g} / 100 \mathrm{~g}$. The close relationship between conduction velocities and ALAD activities, whose inhibition is measurable in vitro at about 10 to $20 \mu \mathrm{g}$ of lead/dl of blood and reaches a maximum at 70 to $90 \mu \mathrm{g}$ of lead/ dl (4), shows that the influence on conduction velocities starts at such a low level of the human body burden of lead. And the multiple regression analysis confirmed more definitely the relationship between lead absorption and the slowing of nerve conduction velocities.

This relationship does not mean, however, that a significant decrease in conduction velocities occurs on an individual level. Since the lower limit of the MCV of the median nerve in the forearm was $48.9 \mathrm{~m} / \mathrm{s}$ in "healthy" people, only 5 out of 19 workers with $\mathrm{PbBs}$ between 29 and $73 \mu \mathrm{g} / 100 \mathrm{~g}$ showed diminished MCVs (fig. 1). This finding suggests that a slight delay in nerve conduction velocities occurs in about $26 \%$ of lead workers at $\mathrm{PbB}$ levels of about $45 \mu \mathrm{g} / 100 \mathrm{~g}$.

The delay in the conduction velocities and the correlations with parameters of 
lead absorption were the most significant for the motor nerves, but the same trends were also found for mixed nerve conduction velocities. Although sensory nerve conduction velocities remained unchanged in all parts of the apper and lower extremities, the involvement of the fastest sensory nerve fibers may not be excluded.

So far as the parts of the upper and lower extremities are concerned, the conduction velocities seemed to be affected mainly in the forearm. The topographical findings seem to be qualitatively similar to the clinical observations that wrist drop is the most frequent phenomenon among muscular paralysis in classical lead poisoning. The topographical nature might have played an important part in the development of localized lead palsy, as well as in predisposing factors such as fatigue (2). Although it is not obvious in the present study if the motor nerve conduction velocity is affected in the palm, the diminished MCV of the median nerve in the forearm may be a manifestation of motor peripheral neuropathy due to lead absorption. The motor nerve involvement in the leg may be consistent with the clinical observation that the paralysis of the lower extremities occurs, though less frequently, in "classical" lead poisoning (2).

\section{ACKNOWLEDGMENTS}

The authors wish to express their thanks to Dr. K. Ushio, vice director of the Tokyo Rosai Hospital, for his interest and kind help. Thanks are also due to Prof. A. Koizumi, Department of Public Health of The University of Tokyo, Associate Prof. T. Nakanishi Department of Neurology of The University of Tokyo, and Prof. Emeritus $H$. Katsunuma, The University of Tokyo, for their encouragement and valuable advice.

\section{REFERENCES}

1. ARAKI, S. Small dose of lead and its effects on man. Igaku-no ayumi [Developments in medical science]. 96 (1976) 70-78. (in Japanese)

2. CANTAROW, A. and TRUMPER, M. Lead poisoning. Williams \& Wilkins, Baltimore, Md. 1944. 126 p.

3. FELDMAN, R. G., HADOW, J., KOPITO, L. and SCHWACHMAN, H. Altered peripheral nerve conduction velocity: Chronic lead intoxication in children. $A m$ j. dis. child. 125 (1973) 39-41.

4. HERNBERG, S. Biochemical, subclinical and clinical responses to lead and their relation to different exposure levels, as indicated by the concentration of lead in blood. Working paper of the 3rd meeting of the subcommittee on the toxicology of metals, Tokyo, 18-23 Nov. 1974.

5. HODES, R., LARRABEE, M. G. and GERMAN, W. The human electromyogram in response to nerve stimulation and the conduction velocity of motor axons. Arch. neurol. psychiat. 60 (1948) $340-365$.

6. SEPPÄLÄINEN, A. M. and HERNBERG S. Sensitive technique for detecting subclinical lead neuropathy. $B r . j$. ind. med. 29 (1972) 443-449.

7. SEPPÄLÄINEN, A. M., TOLA, S., HERNBERG, S. and KOCK, B. Subclinical neuropathy at "safe" levels of lead exposure. Arch. environ. health 30 (1975) $180-183$.

8. SESSA, T., FERRARI, E. and COLUCCI D'AMATO, C. Velocita di conduzione nervosa nei saturnini. Folia med. (Napoli) 48 (1965) 658-668.

9. TAKEUCHI, H., TAKAHASHI, M., HARA, I., HASHIMOTO, K., SUENAKA, T. and GENBA, H. An electrophysiological study on peripheral nerve injuries of workers handling lead. Jap. j. ind. health 17 (1975) $467-474$.

10. WADA, O., YANO, Y., TOYOKAWA, K. SUZUKI, T., SUZUKI, S. and KATSUNUMA, H. Human responses to lead; in special references to porphyrin metabolism in bone marrow erythroid cells, and clinical and laboratory study. Ind. health 10 (1972) 84-92.

11. WEISSBERG, J. B., LIPSCHUTZ, F. and OSKI, F. A. $\delta$-aminolevulinic acid dehydratase activity in circulating blood cells: A sensitive laboratory test for the detection of childhood lead poisoning. New engl. j. med. 284 (1971) 565-569. 